Citation: Ricardo Sellers-Rubio (2021) Wine ratings and advertising strategies: is there a link?. Wine Economics and Policy 10(2): 87-97. doi: 10.36253/ wep-10639

Copyright:@2021 Ricardo Sellers-Rubio. This is an open access, peer-reviewed article published by Firenze University Press (http://www.fupress.com/wep) and distributed under the terms of the Creative Commons Attribution License, which permits unrestricted use, distribution, and reproduction in any medium, provided the original author and source are credited.

Data Availability Statement: All relevant data are within the paper and its Supporting Information files.

Competing Interests: The Author(s) declare(s) no conflict of interest.

\section{Wine ratings and advertising strategies: is there a link?}

\author{
Ricardo Sellers-Rubio \\ University of Alicante, Department of Marketing, Crta. San Vicente s/n. 03690, Alicante, \\ Spain.Email: ricardo.sellers@ua.es
}

\begin{abstract}
Advertising is one of the most widely used marketing resources in the beverage industry, yet the wine industry has not made an intense use of this resource over time. The small average size of wineries together with rising concerns about the effectiveness of advertising has led many wineries to use alternative strategies to market their products: collective brands, the display of prizes and medals on their labels, or positive ratings in expert guides. In this sense, the objective of the present study was to analyse the behaviour of wineries regarding their use of advertising as a marketing resource. Specifically, we analysed the advertising strategy of wineries with respect to the existence of publicly available wine ratings. The method was based on the estimation of a Heckit model that simultaneously identifies the variables underlying the decision to invest in advertising and the determinants of the amount of money invested. The results revealed a nonlinear relationship between wine ratings and advertising investment.
\end{abstract}

Keywords: advertising, Heckit model, wine ratings, winery.

\section{INTRODUCTION}

Food and beverage companies resort to different strategies to promote their products. Among them, advertising is often used to convince consumers to select a specific product over that of competitors, communicating positive and persuasive information about the company and its products to the target market. In fact, advertising can enhance brand awareness [1], brand equity [2] and create a reputation premium, enabling the price of an advertised brand to be higher than that of competing products with the same characteristics [3]. Furthermore, advertising can discourage potential competitors to enter the market [4]. When a firm has a strong market position, an effective use of advertising can be helpful to charge higher prices and increase profits [5].

Despite its potential benefits, there is some uncertainty in the academic literature as to the effectiveness of advertising [6-8]. Some researchers have raised doubts about the relationship between advertising investment and performance [3,9-11]. Several researchers have even found an absence of a link between advertising investment and sales performance [11-16]. Consequently, 
advertising effectiveness is under continuous scrutiny by researchers and practitioners.

In the wine industry, the link between advertising investment and performance is under- researched, and the scarce number of studies that do exist on this topic do not offer conclusive results. On the one hand, [17] provide evidence that advertising might positively impact sales. Their results for the US market show that the advertising of imported wines significantly increases imports for most countries. On the other hand, [18] show that advertising investments are not significantly related to wine sales in the US market at an aggregate level. However, they suggest that in mature markets competition is intense, and firms attempt to increase their revenue and market share through their marketing efforts. The authors can hardly conclude, however, that advertising is the only driver of sales. Indeed, other factors such as brand appeal or discounts may have an impact on sales and revenues.

In Spain, wineries have introduced several marketing and advertising campaigns in the media since the 1980s in order to overcome decreasing domestic demand and growing international competition [19]. The absence of a clear effect, however, of advertising investments on firm performance has led many small wineries to employ alternative marketing strategies, including some which are specific to the wine industry (e.g. fostering high ratings in wine guides). This situation has led to the existence of two different groups of wineries: a first group of wineries that relies on advertising as a powerful marketing strategy (with varying degrees of advertising intensity), and a second group of wineries that do not make these types of investments and rely on alternative strategies. In this paper, we seek to contribute to the literature by exploring the reasons underlying wineries' behaviours. We focus in particular on the effect that wine ratings have on the advertising strategy of Spanish wineries. Wine ratings are frequently used in the wine industry to signal product quality because they represent a useful tool to compensate for information asymmetries between consumers and wineries. Although some authors (e.g. [20-22]) have raised concerns about quality assessment inconsistencies between judges or incoherence by a same judge over time, they still constitute important informative clues for consumers. Indeed, [23] provide evidence that consumers attribute a high credibility to independent expert recommendations. These ratings may, to some extent, affect wineries' advertising strategies.

In this sense, the objective of the present study was twofold. First, we sought to find out the variables that might explain the decision to invest in advertis- ing or not. We propose a model to explain the differences between wineries that do invest in advertising and firms that do not. Furthermore, we tried to explain the amount of money invested in advertising. We focused on the effect that publicly available ratings may have on these strategic advertising decisions. Second, we compared several performance and profitability ratios among these two groups of wineries to assess the effectiveness of advertising investments in the Spanish wine industry.

\section{LITERATURE REVIEW}

\subsection{Advertising effectiveness and the wine industry}

In a mature competitive market, firms have different strategies at their disposal to promote their products [24], such as price discounts, vouchers, increasing the amount of sales staff and points of sale, or advertising, which is a major means of appealing to consumers [25]. Through advertising, firms send a message that allows consumers to obtain information about the firm/ brand and compare it with that of various competitors to make their purchase decisions. In this sense, firms advertise across several media vehicles, striving to build a cohesive message to increase the individual and joint effect of their investment [26]. Advertising can be used to convince consumers to buy a certain brand instead of that of competitors, to increase consumers' loyalty, and to reduce their sensitivity to price which can ultimately raise a firm's market share $[27,28]$.

Given their potential benefits, some scholars have focused on estimating the positive effects expected of advertising investments on different performance and profitability ratios. Most of these studies find a positive effect of advertising investments on performance [27, 29-33]. For example, [30] provide evidence of a longterm relationship between advertising spending and market capitalisation. Their results show that advertising has an effect on firms' market capitalisation through its effect on sales and profits. In the same line, [29] state that a productive firm should be able to expand its market share through advertising. However, some studies have failed to find a clear relationship between advertising and performance $[3,10,30]$ or have even found no link at all between these variables [12, 14-16, 34].

Several explanations have been given to these contradictory results. For example, [34] suggest that advertising effectiveness may differ between expansion and contraction economic periods. They show that advertising investment during recessions may lead to more financial outcomes (e.g. sales) than advertising investment dur- 
ing periods of growth. According to other authors, it is reasonable to expect that not all companies will reap the same benefits from advertising. Thus, [35] claim that the relationship between advertising and performance is not straightforward and other factors, such as advertising intensity or firm size might moderate this relationship. Indeed, certain authors [35-38] have found that bigger firms make a more intense use of advertising and obtain higher returns than smaller firms. In the same line, [33] point out that advertising has a moderate influence on sales in the short and long term. Advertising should thus be considered an adaptive learning process that may take some time to be noticed. [39] provide evidence of robust positive effects of advertising but stress the need to consider the originality and creativity of advertising, as the effects are stronger for high-involvement products compared to low-involvement products.

In the beverage industry, most of the previous literature has focused on analysing the effect of advertising on alcohol consumption at an aggregate level. Contrary to what could be expected a priori, most of the studies found no effect of advertising on total alcohol consumption [40]. However, a recent study [41] suggests a tiny yet consistent positive correlation between alcohol advertising exposure (wine, beer and spirits) and drinking behaviour.

In the specific case of the wine industry, few studies have estimated the effect of advertising on wine consumption, and the scarce number of studies in this area that do exist do not offer conclusive results. On the one hand, [17] illustrate how advertising might have a positive effect on sales in the US market. They show that advertising of imported wines significantly increases the quantity of imports for most countries. On the other hand, [18] show that advertising investments are not significantly related to wine sales in the US market at an aggregate level. However, they do suggest that in mature markets competition among firms is intense. Although firms strive to increase their revenue and market share through marketing efforts, it would be highly unrealistic to suggest that advertising is the only sales driver. Indeed, other promotional activities (e.g. price discounts) may also have an impact on sales, so it would be difficult to precisely determine the effect of advertising on sales without considering these issues. [42] examine advertising effectiveness from the perspective of advertising productivity, showing that it is greater in the case of wineries associated with a collective brand than for non-associated wineries. Their results also indicate that advertising productivity is higher in the case of brands with a better firm reputation, and this result is moderated by the degree of competition.
In the Greek market, [43] show that firms' promotions offering information about the origin and other specific wine attributes, free samples, leaflets or new market channels through "wine routes" are more effective than advertising. Furthermore, according to their results, promotional expenses along with market share affect profitability.

Based on a different perspective, [44] focused on advertising creativity and examined the potential effectiveness of advertising targeted towards Millennials. They showed that current wine advertising is not appealing to this market segment, who would prefer wine advertisements based on fun, social, and relaxed settings. Similarly, [45] found that wine brands should focus their advertising on the social aspects of wine when trying to reach Millennials. In the same line, [46] examine the contents of wine advertising (types of photographs) and their effect on the adoption of technological solutions in this field.

Eventually, [47] have estimated the relationship between advertising investment and reputation in the framework of companies that belong to a collective brand in the Spanish wine industry and invest in advertising. Their results evidence a curvilinear relationship between advertising investment and reputation. Besides, results also show that the market share of the winery negatively moderates this relationship. To some extent, our paper expands this previous article as our sample includes wineries that invest in advertising but also wineries that do not invest in advertising.

\subsection{Wine quality and advertising investment: the role of wine ratings}

The link between quality and advertising investment is a major marketing issue [48] as advertising investment can be informative about product quality. But the complexity of this theoretical relation shows that a clear relationship between quality and advertising investment has in fact not been demonstrated in past research [49].

On the one hand, the signalling theory [50] indicates a positive relationship between quality and advertising investment in the case of experience goods [48] because firms that produce high-quality products might use advertising to signal to consumers their commitment to quality [51, 52]. For example, [53] found that advertising can be a useful signal to improve consumers' evaluations of advertised products. On the other hand, firms with low-quality products may also use advertising to compensate for the loss of quality as advertising differentiates products and reduces demand cross-elasticities. Following this reasoning, product quality and 
advertising investment would present a negative association $[27,54]$. Indeed, the seminal study by [55] suggests a negative relationship, since a high degree of advertising intensity may be used to increase consumer preferences for low quality products [27]. [56] provides a review that shows how different studies offer conflicting evidence in support of these contradictory viewpoints.

In the case of experience products, quality is very difficult to assess before consumption and alternative theoretical approaches consider the link between quality and advertising investment, focusing on reputation. When consumers are not able to assess quality before their purchase, some extrinsic cues may in fact act as a proxy of quality $[57,58]$. For example, in the wine industry, price has played a traditional role as a proxy of wine quality [59]. At the same time, the brand (commercial brand and collective brand like a denomination of origin [60]) may have a role in this sense. In this paper we focus on the potential effect of firm and product reputations. However, prior evidence has also revealed conflicting results. Some studies find a positive association when quality ratings are published and widely disseminated (e.g., [51]). In the same line, [53] illustrate how more highly rated experience products are found to be advertised more. This evidence is consistent with the company reputation model of [52] that assumes that reputation has a positive effect on advertising because firms with high quality products use advertising to inform consumers of their commitment to quality [51]. Conversely, [49] show that available online ratings have a negative effect on advertising investment as firms with higher ratings invest less in advertising, suggesting that reputation through ratings might act as a substitute for advertising investment.

Based on the reasoning above, we adopted in this study the integrated view of [48] according to which a non-linear link exists between quality and advertising investment. In this sense, we propose the following hypothesis:

H1a. Publicly available wine ratings affect the likelihood of investing in advertising.

H1b. Wine ratings have a nonlinear effect on the amount of money invested in advertising.

\section{METHOD AND DATA}

\subsection{Method}

A Heckit model estimation was conducted to explain the advertising strategy of wineries. This model was originally developed by $[61,62]$, and its main advan- tage is to avoid sample selection bias, which involves the incidental truncation that arises when the dependent variable is observed only if other variables take on particular values [63]. Under the Heckit model the dependent variable is only observable for a portion of the data, and this model permits the error terms to co-vary. Thus, in our context, the model decomposes a winery's advertising strategy into two stages: the decision to invest in advertising (or not) and the amount of money invested. The model has been previously used in the wine industry to test the willingness to pay for sustainable wines [64]. The resulting two-equation model was as follows:

$d_{i^{\star}}=\sum_{r=1}^{R} \gamma_{r} W 1_{i r}+u_{i}$

$\operatorname{In} v_{i}=\sum_{s=1}^{S} \beta_{s} W 2_{i s}+\varepsilon_{i}$ observed only if $d_{i^{\star}}>0$

where $W 1_{i r}$ is a vector of $r$ variables related to winery $i$ that determine the decision to invest in advertising $d_{i}$, and $g_{r}$ are the associated parameters. The $d_{i}$ variable is binary, with a unitary value when the latent variable is above zero $\left(d_{i \rtimes}>0\right)$, and zero otherwise. $W 2_{i s}$ is a vector of $s$ variables related to winery $i$ associated with the decision regarding the amount of money invested $\left(\operatorname{In} v_{i}\right)$, and $b_{s}$ reflects the effect of these variables on this decision. It is worth noting that the log-transformation is applied to the dependent variable $\operatorname{Inv}_{i}$, thus semi-elasticities are obtained directly from the parameters. The error terms $u_{i}$ and $e_{i}$ follow a bivariate standard normal distribution, and standard deviations $s_{u}$ and $s_{e}$, and covariance $s_{e u}$. Full information maximum likelihood is used to obtain the parameter estimates. To test the effect of wine ratings on advertising spending, two different models were estimated, including linear (Model 1) and quadratic (Model 2) effects separately. To implement this methodology, we use the sampleSelection library of the statistical package R [65].

\subsection{Sample and variables}

The hypotheses were tested within the framework of the Spanish wine industry. For the sample selection we use the population of wineries included in the 1102 section of CNAE-2009, which is the equivalent of code 2084 of the US SIC classification (wines, brandy and brandy spirits), and is found in the Bureau Van Dijk database. From the initial sample we discarded companies with missing values in any of the relevant variables. Besides, to ensure the homogeneity of the sample, we excluded wineries that mainly produce brandy and other distilled high alcohol products. Following this procedure, the final sample comprised a total of 835 winer- 
ies, operating between 2004 and 2014, and represented more than $70 \%$ of Spain's total wineries' sales revenue over the whole period.

The data was collected and matched based on the sources described next. Data on advertising spending were obtained from the Information for Advertising Expenditures (Infoadex) database (https://www.infoadex. es), which provides information on advertising expenditure in Spanish media in the form of print, broadcast, outdoor, and Internet advertising. Financial, accounting and another specific firm information was obtained from the Bureau Van Dijk database (https://www.bvdinfo.com). Information on designations of origin (DO) was gathered from the publicly available listings of the different DOs and their respective websites. Wine ratings were obtained from the renowned Spanish guide The best wines in Spain (Repsol Guide), which offers expert blind tasting quality scores on a 100-point scale. All monetary values are deflated by the GDP deflator index.

The model's dependent variable is the winery's advertising strategy, which is broken down into two decisions: the decision to invest in advertising (measured through a dummy variable that takes the value of 1 if the winery invests in advertising in period $t$, and 0 elsewhere); and the decision of how much money the winery $i$ invests during period $t$, which is measured in euros $\left(\operatorname{In} v_{i t}\right)$.

The variables listed below are considered to explain the winery's advertising decisions:

i) Number of wine references with ratings (NumRef$s_{j}$ ): this variable reflects the number of wine references marketed by the winery that appear in the guide. Advertising investment can be influenced by this variable because a wider product assortment is more likely to be associated with greater levels of advertising [54].

ii) Wine ratings $\left(W R_{j}\right)$ : this variable is measured through the average quality ratings of the wines marketed by the winery. It is a proxy of the winery's reputation. Wine guides ratings based on sensory assessments are used in the wine industry to measure quality and reputation [66].

iii) Designation of origin $\left(D O_{j}\right)$ : this variable reflects whether the winery belongs to a Designation of Origin that acts as a collective trademark, signaling the origin, nature or quality of the wines. It is measured through a dummy variable that takes the value of 1 if the winery belongs to a Designation of Origin and 0 , otherwise.

iv) Type of designation of origin (DOType $e_{j}$ : this variable is based on the different requirements established to achieve a DO status and is a proxy of the collective trademark reputation [67]. If a winery uses a collective trademark to market its wines, this information will be indicated on the wine's label, which is publicly available to consumers. The Spanish system establishes four different categories of DO wines. Thus, this variable takes a value of 4 for Estate Wines, 3 for Qualified Designations of Origin, 2 for Designations of Origin and 1 for Quality Wines. For wineries that belong to several indications we have considered the highest level of DO type achieved, as we don't know the percentage that every DO represents for the winery.

v) Winery experience (Experience $e_{j}$ ): this variable is measured as the number of years since the winery's establishment. The age of the company is usually associated with its advertising investment. Indeed, the reputation of a firm spreads through positive (or negative) word of mouth once it has been established for the first time [68]. Hence, consumers will have more information about earlier entrants in the market and will depend less on advertising, so later entrants will probably need to invest more in advertising [54].

vi) Winery size $\left(\right.$ Size $\left._{j}\right)$ : this variable is measured based on the winery's volume of assets [69]. This variable is included because firm size can affect advertising investment as larger firms dispose of more financial resources to invest in promotion [70].

The descriptive statistics are shown in Table 1. Of the sample's 835 wineries, 189 invest in advertising and 646 do not. The average monetary amount invested is 51,240 euros per year. A total of 696 wineries belong to a DO, while 139 do not. Of the total, 273 wineries appear in the guide each year, 347 never appear in the guide, and 215 wineries appear only some years. Most of the correlations among the variables are relatively low. However, and as it might be expected, advertising spending and size of the winery are positively correlated (0.553). Besides, the correlation between the variables DO and DOType is closed to 1 .

\section{RESULTS}

First, a Heckit model estimation was conducted to explain the wineries' advertising strategy and to test the proposed hypotheses. The procedure allowed us to identify the drivers of the advertising strategy, which was broken down into the decision to invest (or not) and the decision on the amount of money invested. To test the effect of wine ratings on advertising spending, two different models were estimated, including linear (Model 1) and quadratic (Model 2) effects separately (see Table 2). The variables DO and Experience served as instruments and were included only in the selection equation (Eq.1).

We implemented the two-step Heckman procedure that includes the inverse Mills ratio in the second step as 
Table 1. Descriptive statistics and correlations among variables.

\begin{tabular}{|c|c|c|c|c|c|c|c|c|}
\hline Variable & $\begin{array}{c}\text { Mean } \\
(\mathrm{SD})\end{array}$ & (1) & (2) & (3) & (4) & (5) & (6) & (7) \\
\hline $\begin{array}{l}\text { (1) } \\
\text { AdvSpending }\end{array}$ & $\begin{array}{c}51240 \\
(4783 \text { E02) }\end{array}$ & 1.000 & 0.125 & -0.009 & 0.043 & 0.062 & 0.198 & 0.553 \\
\hline (2) NumRefs & $\begin{array}{c}1.174 \\
(1.713)\end{array}$ & & 1.000 & 0.145 & 0.278 & 0.245 & 0.203 & 0.266 \\
\hline $\begin{array}{l}\text { (3) Wine } \\
\text { ratings }\end{array}$ & $\begin{array}{l}90.486 \\
(1.791)\end{array}$ & & & 1.000 & -0.012 & 0.030 & -0.029 & 0.067 \\
\hline (4) $\mathrm{DO}$ & $\begin{array}{c}0.833 \\
(0.372)\end{array}$ & & & & 1.000 & 0.933 & 0.012 & 0.087 \\
\hline (5) DOType & $\begin{array}{l}2.5579 \\
(1.344)\end{array}$ & & & & & 1.000 & 0.014 & 0.127 \\
\hline (6) Experience & $\begin{array}{c}19.141 \\
(15.658)\end{array}$ & & & & & & 1.000 & 0.274 \\
\hline (7) Size & $\begin{array}{c}9856.6 \\
(31645)\end{array}$ & & & & & & & 1.000 \\
\hline
\end{tabular}

Table 2. Determinant factors of wineries' advertising strategy.

\begin{tabular}{|c|c|c|c|c|c|c|}
\hline & \multicolumn{3}{|c|}{ Model 1} & \multicolumn{3}{|c|}{ Model 2} \\
\hline & Coeff & $S D$ & p-value & Coeff & $S D$ & p-value \\
\hline \multicolumn{7}{|l|}{ Eq.1 } \\
\hline Intercept & -5.084 & 0.151 & $<0.001$ & -5.085 & 0.151 & $<0.001$ \\
\hline NumRefs & 0.289 & 0.011 & $<0.001$ & 0.289 & 0.011 & $<0.001$ \\
\hline$D O$ & 0.512 & 0.078 & $<0.001$ & 0.512 & 0.078 & $<0.001$ \\
\hline Experience & 0.007 & 0.001 & $<0.001$ & 0.007 & 0.001 & $<0.001$ \\
\hline Size & 0.390 & 0.016 & $<0.001$ & 0.390 & 0.016 & $<0.001$ \\
\hline \multicolumn{7}{|l|}{$\overline{\text { Eq. } 2}$} \\
\hline Intercept & 6.973 & 2.736 & 0.011 & 211.426 & 82.005 & 0.009 \\
\hline NumRefs & 0.043 & 0.034 & 0.209 & 0.045 & 0.034 & 0.186 \\
\hline Wine ratings & -0.015 & 0.029 & 0.610 & -4.551 & 1.818 & 0.012 \\
\hline Wine ratings $(\wedge 2)$ & & & & 0.025 & 0.010 & 0.012 \\
\hline DOType & 0.049 & 0.063 & 0.431 & 0.041 & 0.063 & 0.512 \\
\hline Size & 0.455 & 0.067 & $<0.001$ & 0.431 & 0.067 & $<0.001$ \\
\hline lambda & -0.361 & 0.176 & 0.040 & -0.378 & 0.181 & 0.037 \\
\hline Log-L & -6357.247 & & & -6354.139 & & \\
\hline Sigma & 1.816 & & & 1.815 & & \\
\hline Rho $(\rho)$ & -0.199 & & & -0.208 & & \\
\hline Obs. & 8351 & & & 8351 & & \\
\hline
\end{tabular}

a regressor. Results show that the coefficient of this variable $(\lambda)$ is significant in both models. Besides, the results showed significant correlations $(\rho)$, which proves that the correlation between the disturbances of the decision to invest in advertising and the amount of money invested is significantly different from zero. The latter shows the advantages offered by the Heckit model for this analy- sis as it permits the error terms to co-vary. Moreover, it confirms the two-step managerial decision process: first, the decision to invest (or not) in advertising and, second, the amount of money invested.

Regarding the determining factors of the decision to invest in advertising (Eq. 1), all the variables included were significant. According to the results, the num- 
ber of wine references in the portfolio included in the guide was significant, showing that a wider assortment of products with available quality ratings is associated with a greater probability of investment in advertising [54]. This result supports Hypothesis 1a, implying that wine ratings are not substitutes for advertising. It seems that wineries that produce quality wines wish to inform consumers of their commitment. In addition, the results also provide evidence that wineries that belong to a DO are more likely to invest in advertising. Despite the fact that the collective trademark reputation might help to market the wines, the results showed that it is more likely that wineries with a DO decide to invest in advertising, probably to reinforce their market position. Ultimately, the control variables that reflect a winery's experience and size were also significant in the selection equation (Eq.1). The latter finding shows that market pioneer entrants are more likely to invest in advertising than later entrants. Furthermore, firm size was positively and significantly associated with advertising investment, which suggests that larger wineries are more likely to invest in advertising. An explanation could be that big companies have more resources to invest in promotion than smaller ones [70]. These results were robust in Models 1 and 2.

In relation to the determinants of the amount of money invested in advertising (Eq.2), the estimations generated interesting insights. Model 1 proposes a linear relationship between wine ratings and advertising investment, while Model 2 proposes a nonlinear relationship. First, the number of wine references with publicly available ratings was also non-significant, so this variable did not have any influence on the amount of money invested. However, the results showed that the average rating of the wines included in the guide was not significant in Model 1, where a linear relationship was assumed. For its part, Model 2 illustrates a $\mathrm{U}$-shaped relationship between wine ratings and the amount of money invested (the parameter of the variable WR is negative and significant and the parameter of the variable WR $(\wedge 2)$ is positive and significant). These results show that wineries with low-level average ratings and wineries with high-level average ratings invest more money in advertising than wineries with medium- level average ratings. These results confirm Hypothesis $1 b$ as publicly available wine ratings (which act as a proxy of the winery's reputation) have a nonlinear effect on the amount of money invested in advertising. It seems that the number of references appearing in the guide presents less significance than the average valuation of these wines, which can act as a sign of reputation [66] and better reflect the winery's commitment to quality.
In both models, the DO type variable is non-significant, implying that the collective reputation of the different DO types does not influence the amount of money invested in advertising. Finally, as expected, the winery's size also exerts a positive effect on the amount of money invested in advertising.

In the second stage, traditional profitability indexes were estimated to test the differences between wineries that invest in advertising and wineries that do not. We also tested the difference between wineries with (and without) publicly available wine ratings. Specifically, the traditional returns on assets (ROA), returns on equity (ROE) and returns on investments (ROI) ratios were computed. Results are shown in Table 3.

The average profitability ratios were 0.6 per cent for ROA, 4.2 per cent for ROE and 6.9 per cent for ROI. To test the differences between investing and non-investing in advertising wineries a two-tailed t-test was performed. This test accounts for the possibility of the relationship in both directions. In this sense, the ROA was higher for investing wineries while the ROE was higher for non-investing wineries, and these differences were statistically significant. Furthermore, the ROA was higher for wineries with publicly available ratings while the ROE was higher for wineries without publicly available ratings, and these differences were also statistically significant. However, no significant differences appeared when considering ROI as a performance measure. Nevertheless, much caution should be exercised, because performance ratios do not give the whole picture of winery performance. This descriptive approach shows that

Table 3. ROI, ROE and ROA estimates.

\begin{tabular}{|c|c|c|c|c|}
\hline & & ROA & ROE & ROI \\
\hline \multicolumn{5}{|c|}{ Advertising } \\
\hline \multirow[t]{2}{*}{ Yes } & Mean & 0,018 & 0,021 & 0,048 \\
\hline & $(\mathrm{SD})$ & $(0,074)$ & $(0,268)$ & $(0,344)$ \\
\hline \multirow[t]{3}{*}{ No } & Mean & 0,002 & 0,048 & 0,075 \\
\hline & (SD) & $(0,071)$ & $(0,576)$ & $(1,424)$ \\
\hline & Test difference & $\begin{array}{c}t=-9,084 \\
(p=0,000)\end{array}$ & $\begin{array}{c}t=2,062 \\
(p=0,039)\end{array}$ & $\begin{array}{c}t=0,877 \\
(p=0,380)\end{array}$ \\
\hline \multicolumn{5}{|c|}{ Public wine ratings } \\
\hline \multirow[t]{2}{*}{ Yes } & Mean & 0,012 & 0,030 & 0,054 \\
\hline & $(\mathrm{SD})$ & $(0,075)$ & $(0,428)$ & $(0,819)$ \\
\hline \multirow[t]{3}{*}{ No } & Mean & 0,001 & 0,052 & 0,083 \\
\hline & (SD) & $(0,069)$ & $(0,592)$ & $(1,547)$ \\
\hline & Test difference & $\begin{array}{c}t=-7,623 \\
(p=0,000)\end{array}$ & $\begin{array}{c}\mathrm{t}=1,981 \\
(\mathrm{p}=0,048)\end{array}$ & $\begin{array}{c}\mathrm{t}=1,102 \\
(\mathrm{p}=0,270)\end{array}$ \\
\hline \multirow{2}{*}{\multicolumn{2}{|c|}{$\begin{array}{c}\text { Total Mean } \\
\text { (SD) }\end{array}$}} & 0,006 & 0,042 & 0,069 \\
\hline & & $(0,072)$ & $(0,522)$ & $(1,262)$ \\
\hline
\end{tabular}


no one-size-fits-all strategy exists, since no robust and consistent differences can be obtained regarding the performance of wineries that invest (or not) in advertising and the wineries that appear (or not) in publicly available quality ratings. These results are consistent with the findings of other studies that have failed to find a clear association between advertising investment and performance (e.g. [11]).

In this paper we have focused on the potential effect of wine ratings (a signal of reputation) on the advertising strategy of a winery. Although prior evidence has revealed conflicting results, our results evidence a positive association between the existence of publicly available quality ratings and advertising investment, what is in line with [51]. Besides, our results are aligned with [53], who evidence that more highly rated experience products are advertised more. In this sense, this evidence is consistent with the company reputation model [52]. When it comes to the association between advertising and performance, our results are aligned with [11], as the relationship between advertising and performance is not clearly supported.

\section{CONCLUSIONS}

In the wine industry, some firms make the decision to invest while others foster alternative marketing strategies to promote their wines. Despite the potential benefits of advertising, the lack of a clear link between advertising investments and performance and the small average size of wineries might explain why the intensity of this resource is very low in this industry compared to other beverage industries. Thus, alternative marketing strategies - such as promoting positive worth of mouth, the presence of medals and awards on wine labels or fostering ratings in the best-known wine guides- are frequently used by wineries [71]. Wine ratings are particularly popular in the wine industry because they offer consumers a signal of wine quality which they can rely on to make informed purchase decisions. In this paper, we focused on the effect of these publicly available wine ratings on wineries' advertising strategy.

The results of the present study showed that the number of wine references with publicly available wine ratings in wine guides has a positive influence on the winery's likelihood to invest in advertising. Moreover, the results provide evidence of a U-shaped relationship between wine ratings and advertising investment: wineries with low and high average wine ratings invest greater amounts of money than firms with medium wine ratings.
According to [72] the most effective means of communication in the wine industry is word of mouth, since most consumers often follow other people's recommendation when buying wines. To spread a positive word of mouth, wineries can employ different strategies, from direct visits to wineries to advertising, which is considered the last item in the communication mix. In fact, long-term advertising is an effective tool to communicate the winery's positioning in the market [72]. From a managerial viewpoint, two important decisions regarding the advertising strategy are made. First, managers decide whether to invest in advertising or not, and in a second stage, they decide which amount of money should be invested. Bearing in mind that the wineries aim to choose the best available strategy to promote their wines, no one-size-fits-all strategy seems to exist. While some wineries invest in advertising, others rely on collective brands (DO) to promote their wines. Our results showed that the wineries that belong to a $\mathrm{DO}$ are more likely to invest in advertising. In addition, the number of wines with publicly available wine ratings also has a positive influence on the probability of investing in advertising: it seems that wineries seek to inform consumers of their commitment to quality. Once the winery has decided to invest in advertising, it must determine the amount of money to be invested. Our results demonstrate that this strategy is employed by low- and high-quality producers. Indeed, wineries with low ratings would use advertising to convince consumers to buy their wines, while wineries with high ratios also strive to reinforce their market position to attract consumers. Both types of wineries attempt to spend their advertising budgets effectively while meeting customer needs.

The present work presented several limitations that should be addressed in future studies. First, only two dimensions of wineries' advertising strategy were explored: the decision to invest or not and the amount of money invested. However, other decisions, such as the media employed or advertisements' content and creativity, were not considered. They are, however, also part of wineries' advertising strategy. Second, this paper only considered one Spanish wine guide (i.e. the Repsol guide) as the publicly available rating variable. Despite being very well-known during the sample period, it is not the only guide available to consumers. For example, other professional guides such as "Peñin" or "Gourmets" are also very popular in Spain. Future research should address these limitations. In the same way, it would be interesting to consider the influence of publicly available rating that are not professional. Indeed, wine ratings featuring in user-generated platforms, such as Vivino, have 
become very popular in recent years and they may also affect the advertising strategies of wineries.

\section{REFERENCES}

[1] C. R. Clark, U. Doraszelski, M. Draganska, The effect of advertising on brand awareness and perceived quality: An empirical investigation using panel data, Qme 7(2) (2009) 207-236.

[2] K. Jedidi, C. F. Mela, S. Gupta, Managing advertising and promotion for long-run profitability, Mark. Sci. 18(1) (1999) 1-22.

[3] G. Erickson, R. Jacobson, Gaining Comparative Advantage Through Discretionary Expenditures: The Returns to R\&D and Advertising, Manag. Sci. 38(9) (1992) 1264-1279, https://doi.org/10.1287/ mnsc.38.9.1264.

[4] Y. K. Ho, H. T. Keh, J. M. Ong, The effects of R\&D and advertising on firm value: An examination of manufacturing and nonmanufacturing firms, IEEE Trans. Eng. Manag. 52(1) (2005) 3-14.

[5] G. S. Low, J. J. Mohr, Advertising vs sales promotion: a brand management perspective, J. Prod. Brand Manag. 9(6) (2000) 389-414, https://doi. org/10.1108/10610420010356984.

[6] D. A. Aaker, J. M. Carman, Are you over-advertizing, J. Advert. Res. 22(4) (1982) 57-70.

[7] A. Pergelova, D. Prior, J. Rialp, Assessing advertising efficiency, J. Advert. 39(3) (2010) 39-54.

[8] G. J. Tellis, Effective advertising: Understanding when, how, and why advertising works. Sage Publications, 2003.

[9] S. Camino-Mogro, Does Investment in Advertising Boost Economic Performance? Firm-Level Evidence of Ecuadorian Manufacturing, J. Technol. Manag. Innov. 14(4) (2019) 100-118, https://doi. org/10.4067/S0718-27242019000400100.

[10] B. H. Han, D. Manry, The value-relevance of R\&D and advertising expenditures: Evidence from Korea, Int. J. Account. 39(2) (2004) 155-173, https://doi.org/10.1016/j.intacc.2004.02.002.

[11] A. Joshi, D. M. Hanssens, Movie advertising and the stock market valuation of studios: A Case of “Great Expectations?", Mark. Sci. 28(2) (2009) 239250, https://doi.org/10.1287/mksc.1080.0392.

[12] S. Z. Ali Shah and S. Akbar, Value relevance of advertising expenditure: A review of the literature, Int. J. Manag. Rev. 10(4) (2008) 301-325, https:// doi.org/10.1111/j.1468-2370.2007.00228.x.

[13] D. M. Hanssens, L. J. Parsons, R. L. Schultz, Market Response Models: Econometric and Time Series Analysis. Springer Science \& Business Media, 2003.
[14] R. E. Kihlstrom, M. H. Riordan, Advertising as a signal, J. Polit. Econ. 92 (1984) 427-450, https:// doi.org/10.1086/261235.

[15] H. I. Mesak, An aggregate advertising pulsing model with wear out effects, Mark. Sci. 11(3) (1992) 310-326, https://doi.org/10.1287/ mksc.11.3.310.

[16] P. Milgrom, J. Roberts, Price and advertising signals of product quality, J. Polit. Econ. 94(4) (1986) 796-821, https://doi.org/10.1086/261408.

[17] A. G. Sam, S. R. Thompson, Country of origin advertising and US demand of imported wine: an empirical analysis, Appl. Econ. Lett. 19 (2012) 1871-1877.

[18] G. B. Wilcox, E. Y. Kang, L. A. Chilek, Beer, wine, or spirits? Advertisings impact on four decades of category sales, Int. J. Advert. 34 (2015) 641-657, https://doi.org/10.1080/02650487.2015.1019961.

[19] G. Alcaraz-Mármol, F. J. Medina-Albaladejo, Adapting marketing strategies: a linguistic analysis of wine advertising in Spain, 1970-2010, J. Evol. Stud. Bus. 4 (2019) 1, https://doi.org/10.1344/ jesb2019.1.j054.

[20] R. H. Ashton, Reliability and consensus of experienced wine judges: Expertise within and between, J. Wine Econ. 7(1) (2012) 70-87.

[21] R. H. Ashton, Is there consensus among wine quality ratings of prominent critics? An empirical analysis of red Bordeaux, 2004-2010, J. Wine Econ. 8(2) (2013) 225.

[22] R. T. Hodgson, An examination of judge reliability at a major US wine competition, J. Wine Econ. 3 (2008) 105-113.

[23] A. G. Parsons, A. Thompson, Wine recommendations: who do I believe?, Br. Food J. 111(9) (2009) 1003-1015, https://doi. org/10.1108/00070700910992899.

[24] D. W. Carlton, J. M. Perloff, K. T. vant Veld, Modern industrial organization. Scott, Foresman/Little, Brown Higher Education Glenview, IL, 1990.

[25] R. Sethuraman, G. J. Tellis, R. A. Briesch, How well does advertising work? Generalizations from metaanalysis of brand advertising elasticities, J. Mark. Res. 48(3) (2011) 457-471.

[26] S. Sridhar, F. Germann, C. Kang, R. Grewal, Relating online, regional, and national advertising to firm value, J. Mark. 80 (2016) 39-55.

[27] W. S. Comanor, T. A. Wilson, Advertising and Market Power. Harvard University Press, 1974.

[28] C. R. Taylor, S. Zou, A. Özsomer, Advertising and its effect on industrial concentration: A contingency perspective, J. Curr. Issues Res. Advert. 18 (1996) 35-44. 
[29] J. Chen, G. Waters, Firm efficiency, advertising and profitability: Theory and evidence, Q. Rev. Econ. Finance 63 (2017) 240-248, https://doi. org/10.1016/j.qref.2016.04.004.

[30] A. Joshi, D. M. Hanssens, The direct and indirect effects of advertising spending on firm value, J. Mark. 74 (2010) 20-33.

[31] A. Kirmani, P. Wright, Money talks: perceived advertising expense and expected product quality, J. Consum. Res. 16 (1989) 344, https://doi. org/10.1086/209220.

[32] C. F. Mela, S. Gupta, D. R. Lehmann, The long-term impact of promotion and advertising on consumer brand choice, J. Mark. Res. 34(2) (1997) 248-261, https://doi. org/10.1177/002224379703400205.

[33] E. C. Osinga, P. S. H. Leeflang, S. Srinivasan, J. E. Wieringa, Why do firms invest in consumer advertising with limited sales response? a shareholder perspective, J. Mark. 75 (2011) 109-124, https:// doi.org/10.1509/jm.75.1.109.

[34] K. D. Frankenberger, R. C. Graham, Should firms increase advertising expenditures during recessions?, MSI Rep. 3 (2003) 65-85.

[35] A. Assaf, A. Josiassen, A. S. Mattila, L. Kneževic Cvelbar, Does advertising spending improve sales performance?, Int. J. Hosp. Manag. 48 (2015) 161166, https://doi.org/10.1016/j.ijhm.2015.04.014.

[36] K. W. Chauvin, M. Hirschey, Advertising, R\&D expenditures and the market value of the firm, Financ. Manag. 22 (1993) 128, https://doi. org $/ 10.2307 / 3665583$.

[37] L. L. Eng, H. T. Keh, The Effects of advertising and brand value on future operating and market performance, J. Advert. 36 (2007) 91-100, https://doi. org/10.2753/JOA0091-3367360407.

[38] S. Sun, Foreign Entry and firm advertising intensity: evidence from China, Rev. Ind. Organ. 45 (2014) 79-97, https://doi.org/10.1007/s11151-0149426-z.

[39] S. Rosengren, M. Eisend, S. Koslow, M. Dahlen, A meta-analysis of when and how advertising creativity works, J. Mark. 84 (2020) 39-56, https://doi. org/10.1177/0022242920929288.

[40] H. Saffer, D. Dave, Alcohol consumption and alcohol advertising bans, Appl. Econ. 34 (2002) 13251334.

[41] J. Niederdeppe, R. J. Avery, E. Tabor, N. W. Lee, B. Welch, C. Skurka, Estimated televised alcohol advertising exposure in the past year and associations with past 30-day drinking behavior among American adults: results from a secondary analysis of large-scale advertising and survey data, Addiction 116 (2021) 280-289, https://doi.org/10.1111/ add.15088.

[42] F. Mas-Ruiz, F. Sancho-Esper, R. Sellers-Rubio, The effect of collective brand on advertising productivity, Br. Food J. 118 (2016) 2475-2490, https://doi. org/10.1108/BFJ-01-2016-0032.

[43] A. Vlachvei, O. Notta, I. Ananiadis, Does advertising matter? An application to the Greek wine industry, Br. Food J. 111 (2009) 686-698, https:// doi.org/10.1108/00070700910972378.

[44] E. C. Thach, J. E. Olsen, Market segment analysis to target young adult wine drinkers, Agribusiness 22 (2006) 307-322, https://doi.org/10.1002/ agr.20088.

[45] N. Barber, T. Dodd, R. Ghiselli, Capturing the younger wine consumer, J. Wine Res. 19(2) (2008) 123-141, https://doi. org/10.1080/09571260802622225.

[46] S. Sillani, A. Miccoli, F. Nassivera, Different preferences for wine communication, Wine Econ. Policy 6(1) (2017) 28-39, https://doi.org/10.1016/j. wep.2017.03.002.

[47] R. Sellers-Rubio, F. Mas-Ruiz, F. Sancho-Esper, Reputation and advertising of collective brand members in the wine industry: the moderating role of market share, J. Wine Econ. (2021) 1-20, https:// doi.org/10.1017/jwe.2020.52.

[48] I. J. Horstmann, S. Moorthy, Advertising spending and quality for services: The role of capacity, Quant. Mark. Econ. 1(3) (2003) 337-365.

[49] B. Hollenbeck, S. Moorthy, D. Proserpio, Advertising strategy in the presence of reviews: An empirical analysis, Mark. Sci. 38 (2019) 793-811.

[50] P. Nelson, Advertising as information, J. Polit. Econ. 82 (1974) 729-754, https://doi. org/10.1086/260231.

[51] R. B. Archibald, C. A. Haulman, C. E. Moody Jr., Quality, price, advertising, and published quality ratings, J. Consum. Res. 9 (1983) 347-356, https:// doi.org/10.1086/208929.

[52] B. Klein, K. B. Leffler, The Role of market forces in assuring contractual performance, J. Polit. Econ. 89 (1981) 615-641, https://doi.org/10.1086/260996.

[53] N. S. Sahni, H. S. Nair, Does Advertising serve as a signal? evidence from a field experiment in mobile search, Rev. Econ. Stud. 87 (2020) 1529-1564, https://doi.org/10.1093/restud/rdz053.

[54] G. J. Tellis, C. Fornell, The relationship between advertising and product quality over the product life cycle: A contingency theory, J. Mark. Res. 25 (1988) 64-71. 
[55] R. Dorfman, P. O. Steiner, Optimal advertising and optimal quality, Am. Econ. Rev. 44(5) (1954) 826836.

[56] K. Bagwell, The Economic Analysis of Advertising, in Handbook of Industrial Organization 3, M. Armstrong and R. Porter, Eds. Elsevier, 2007 pp.1701-1844. https://doi.org/10.1016/S1573448X(06)03028-7.

[57] M.P. Sáenz-Navajas, E. Campo, A. Sutan, J. Ballester, D. Valentin, Perception of wine quality according to extrinsic cues: The case of Burgundy wine consumers, Food Qual. Prefer. 27 (2013) 44-53, https://doi.org/10.1016/j.foodqual.2012.06.006.

[58] S. Troiano, F. Marangon, T. Tempesta, D. Vecchiato, Organic vs local claims: substitutes or complements for wine consumers? A marketing analysis with a discrete choice experiment, New Medit, 2 (2016) 14-21.

[59] F. Boncinelli, A. Dominici, F. Gerini, E. Marone, Consumers wine preferences according to purchase occasion: Personal consumption and gift-giving, Food Qual. Prefer. 71 (2019) 270-278, https://doi. org/10.1016/j.foodqual.2018.07.013.

[60] G. Scozzafava, F. Gerini, A. Dominici, C. Contini, L. Casini, Reach for the stars: The impact on consumer preferences of introducing a new toptier typology into a PDO wine, Wine Econ. Policy 7(2) (2018) 140-152, https://doi.org/10.1016/j. wep.2018.09.001.

[61] J. J. Heckman, Sample selection bias as a specification error, Econometrica 47(1) (1979) 153-161, https://doi.org/10.2307/1912352.

[62] J. J. Heckman, The common structure of statistical models of truncation, sample selection and limited dependent variables and a simple estimator for such models, Annals Econ. Soc. Meas. 5 (1976) 475-492.

[63] J. M. Wooldridge, Econometric analysis of cross section and panel data. MIT Press, 2010.

[64] R. Sellers-Rubio, J. L. Nicolau-Gonzalbez, Estimating the willingness to pay for a sustainable wine using a Heckit model, Wine Econ. Policy 5(2) (2016) 96-104, https://doi.org/10.1016/j. wep.2016.09.002.

[65] O. Toomet, A. Henningsen, Sample selection models in R: Package sampleSelection, J. Stat. Softw. 27 (2008) 1-23.

[66] B. A. Benjamin, J. M. Podolny, Status, quality, and social order in the California wine industry, Adm. Sci. Q. 44 (1999) 563-589.

[67] R. Sellers-Rubio, F. Mas-Ruiz, F. Sancho-Esper, Firm reputation, advertising investment, and price premium: The role of collective brand membership in high-quality wines, Agribusiness 34(2) (2018) 351-362, https://doi.org/10.1002/agr.21526.

[68] R. R. Thomas, R. S. Barr, W. L. Cron, J. W. Slocum, A process for evaluating retail store efficiency: a restricted DEA approach, Int. J. Res. Mark. 15(5) (1998) 487-503, https://doi.org/10.1016/S01678116(98)00021-4.

[69] R. Sellers, V. Alampi-Sottini, The influence of size on winery performance: Evidence from Italy, Wine Econ. Policy 5(1) (2016) 33-41, https://doi. org/10.1016/j.wep.2016.03.001.

[70] S. Castriota, M. Delmastro, The economics of collective reputation: Evidence from the wine industry, Am. J. Agric. Econ. 97 (2015) 469-489.

[71] U. R. Orth, P. Krška, Quality signals in wine marketing: the role of exhibition awards, Int. Food Agribus. Manag. Rev. 4 (2001) 385-397.

[72] T. Spawton, Marketing planning for wine, Int. J. Wine Mark. 2 (1990) 2-49. 